\title{
ОСОБЛИВОСТІ ПРАВОВОГО СТАТУСУ ВІЙСЬКОВОЇ ЧАСТИНИ ЯК СУБ’ЄКТА ГОСПОДАРСЬКОЇ ДІЯЛЬНОСТІ
}

Розглянуто проблеми подальшого удосконалення правового статусу військової частини як суб'єкта господарської діяльності у Збройних Силах Украӥни. Визначено порядок реєстрачії господарської діяльності військових частин Збройних Сил України. Висвітлено роль Міністерства оборони Украӥни як засобу реалізації повноважень військових частин у сфері господарської діяльності. Сформульовано пріоритетні державні завдання щеоо підвищення ефективності господарської діяльності у Збройних Силах України та удосконалення законодавства України щуодо правового статусу військових частин як основного суб'єкта господарської діяльності.

Ключові слова: військова частина; законодавство; господарська діяльність; Міністерство оборони Украӥни; Збройні Сили Украӥни.

Постановка проблеми в загальному вигляді. На сьогодні необхідною умовою успішного виконання поставлених завдань Збройними Силами України $є$ законодавче визначення правового статусу військової частини як основного суб'єкта господарської діяльності, що тягне за собою появу нових законів України стосовно господарської діяльності військових частин. Одним iз таких нормативно-правових актів $є$ Закон України «Про господарську діяльність у Збройних Силах України». Це, безумовно, викликає необхідність відповідних наукових досліджень, спрямованих на удосконалення правового статусу військової частини як суб'єкта господарської діяльності, оскільки зараз на Збройні Сили України покладено основні функції із захисту територіальної цілісності України.

Аналіз останніх досліджень і публікацій. Окремі проблеми, пов'язані 3 господарською діяльністю військових частин, розглядалися представниками господарсько-правової, цивільно-правової, земельно-правової, військовоадміністративної науки. У працях В.К. Бєлова, П. П. Богуцького, О. М. Вінник, О. Р. Зельдії, І. В. Кириленка, П. М. Кондика, А. В. Кудашкіна, І. Ю. Марка, В. І. Мунш, Ю. А. Поніматченка, О. М. Суркова порушувалися загальні питання організації військового господарювання, ознак правового, режиму військово-господарської діяльності на сучасному етапі існування Збройних Сил України як одного з різновидів спеціального суб'єкту господарювання. Окремим аспектам правового статусу майна, закріпленого за військовими частина, зокрема, отриманого від їх власної господарської діяльності, присвячено праці А. В. Венедиктова, В. В. Віноградова, В. В. Лєсового, О. М. Пащеі, М. 3. Романюка, В. С. Щербини та Л. М. Сморчкової. 
Мета статті - вивчення принципових положень законодавства України щодо існуючої системи реєстрації військової частини як основного суб'єкта господарської діяльності у Збройних Силах України, обліку, списання та інвентаризації військового майна.

Відповідно до цього у статті зосереджено увагу на виконанні таких основних завдань:

- охарактеризувати специфіку військово-господарської діяльності ЗСУ на сучасному етапі їх існування, а також дослідити стан та особливості іiі правового регулювання;

- висвітлити правову природу й уточнити поняття господарськодохідної діяльності, що здійснюється військовими частинами ЗСУ;

- визначити господарсько-правовий статус військових частин, а також особливості правового режиму майна, закріпленого за військовими частинами як суб'єктами господарювання.

Методи дослідження. У дослідженні використано систему різних методів та прийомів наукового пізнання. Серед них основна роль належить діалектичному, системному й формально-логічному, за допомогою яких досліджуються роль і місце інституту господарської діяльно збройних сил, а також споріднених із ним інших інститутів військово-господарського права в системі господарського законодавства України, реалізація ідеї збалансованого урахування публічних і приватних інтересів у специфічних умовах правового режиму господарювання військових частин, співвідношення загальних і спеціальних норм права в цій сфері, сутність (правова природа) господарської діяльності Збройних Сил України.

Досягнення мети дослідження сприяло комплексне застосування етимологічно-телеологічного, семантичного й системного методів аналізу правових норм, зокрема при з'ясуванні господарської правосуб'єктності військових частин правового режиму державного майна, закріпленого за Збройними Силами України, особливості його використання в господарській діяльності військ.

Виклад основного матеріалу дослідження. Відповідно до статті 17 Конституції України на Збройні Сили України покладено обов'язок захисту суверенітету територіальної цілісності й недоторканості нашої держави.

Основу структури Збройних Сил України становлять військові частини, оскільки саме в них вирішується більшість питань бойової підготовки та адміністративно-господарської діяльності.

Закон України «Про господарську діяльність у Збройних Силах України» у статті 3 визначає перелік суб'єктів, що здійснюють господарську діяльність у збройних силах.

Згідно з цією нормою суб'єктами господарської діяльності у Збройних Силах України $є$ військові частини, заклади, установи й організації Збройних Сил України, що утримуються за рахунок коштів державного бюджету країни, ведуть відокремлене господарство, мають кошторис надходжень і 
видатків, рахунки в установах банків, печатку із зображенням Державного Герба України та своїм найменуванням [1].

Таким чином, військові частини, заклади, установи, організації й інші структури збройних сил і раніше, зокрема за часів колишнього СРСР, були учасниками цивільно-правових та господарсько-правових відносин. Проте їх правосуб'єктність значно обмежувалася. Деякі цивільно-правові й господарсько-правові аспекти функціонування збройних сил, зокрема порядок утворення і діяльності військових частин, у той час регулювалися фрагментарно на рівні відомчих нормативно-правових актів.

Варто також підкреслити, що в українському законодавстві військові частини як суб'єкти господарської діяльності можуть використовуватися в узагальненому розумінні, містячи перелік усіх вище зазначених суб'єктів [2, 4-7].

Відповідно до Положення про військове (корабельне) господарство Збройних Сил України під військовими частинами розуміються частини, що входять до складу з'єднань, окремі частини, кораблі, установи, військовонавчальні заклади, об'єкти й організації Збройних Сил України, які ведуть своє господарство, а також адміністративно-господарські частини, відділення, відділи, управління та інші господарські підрозділи, органи військового управління відповідних рівнів, на які покладено завдання щодо матеріального й технічного забезпечення діяльності цих органів i ï особового складу [3].

Аналіз норм, що регулюють господарську діяльність у Збройних Силах України, дозволяє виділити деякі ознаки вказаних суб'єктів.

По-перше, це структури, що утримуються за рахунок коштів державного бюджету.

По-друге, наявність відокремленого господарства. Відповідно до законодавства під відокремленим слід розуміти функціонування у військовій частині відповідних служб забезпечення: фінансової, речової, пальномастильних матеріалів, квартирно-експлуатаційної, медичної, технічного забезпечення, продовольчої тощо. Фактично під відокремленістю господарства частини мається на увазі іiі майнова відокремленість як ознака відокремленості юридичної особи від інших юридичних осіб та держави.

Наступними ознаками суб'єкта господарської діяльності є наявність у військової частини кошторису надходжень і видатків та рахунків в установах банків.

Думки й праці вчених i практиків, у яких можна знайти більше теоретичних досліджень із проблематики правового регулювання у сфері оборони, 3 правових аспектів провадження військовими частинами економічної та господарської діяльності неоднозначні. Спільним є визнання того, що армія не може стояти осторонь процесів реформування економіки, а отже, ці частини мають бути повноправними учасниками цивільно-правових $\mathrm{i}$ господарсько-правових відносин [2, 4-7].

Здійснення структурами збройних сил господарської діяльності має виключно дозвільний характер. 3 теоретичних позицій маємо класичну 
форму взаємовідносин «по вертикалі й горизонталі», тобто регулювання стосунків органів господарського управління та господарюючих суб'єктів.

Говорячи про види господарської діяльності, необхідно звернути увагу на те, що на підставі ч. 2 Закону України «Про господарську діяльність у Збройних Силах України» перелік видів господарської діяльності, здійснення якої дозволяється вказаним частинам, визначений постановою Кабінету Міністрів України від 25 липня 2000 року № 1171 «Про затвердження переліку видів господарської діяльності, здійснення якої дозволяється військовим частинам Збройних Сил» [4].

Затверджений перелік є досить специфічним, оскільки складений 3 урахуванням положень Державного класифікатора видів економічної діяльності, затвердженого Наказом Державного комітету зі стандартизації, метрології та сертифікації від 22 жовтня 1996 року № 441. Специфіка переліку полягає в тому, що він визначає не тільки види діяльності для частин збройних сил, а й для інших військових формувань. Перелік містить широкий спектр видів названої діяльності, що дозволяється провадити військовим частинам [5].

Крім того він підкреслює, що військові частини, що займаються оптовою та роздрібною торгівлею, реалізовують тільки ту продукцію, що виробляється ними безпосередньо. Ці військові частини не можуть реалізовувати закріплене за ними військове майно й займатися посередницькою діяльністю.

Також ч. 3 ст. 3 Закону України «Про господарську діяльність у Збройних Силах України» визначено, що господарська діяльність, яка підлягає ліцензуванню, здійснюється військовими частинами після одержання у встановленому законом порядку ліцензії без справляння плати за їі видачу.

Цей закон закріплює загальні особливості відповідальності військової частини як суб'єкта господарської діяльності. За невиконання чи неналежне виконання договірних зобов'язань, а також шкоду й збитки, заподіяні довкіллю, правам та інтересам фізичних і юридичних осіб та державі, військова частина як суб'єкт господарської діяльності несе відповідальність, передбачену законом і договором. Вона відповідно до своїх зобов'язань відповідає коштами, що надходять на iï рахунок по відповідних статтях кошторису (крім захищених статей), а в разі їх недостатності відповідальність несе Міністерство оборони України. Стягнення за зобов'язаннями військової частини не може бути накладено на майно, за нею закріплене.

Обмеження або припинення іiі господарської діяльності може бути здійснено за рішенням Міністерства оборони України [1].

Отже, можна підсумувати, що військова частина є основним суб'єктом господарської діяльності у Збройних Силах України, ураховуючи те, що законодавець під нею часто узагальнено має на увазі військові частини, установи, організації й інші структури збройних сил.

Згідно зі ст. 4 Закону України «Про господарську діяльність у Збройних Силах України» порядок реєстрації військових частин як суб'єктів 
господарської діяльності у Збройних Силах України визначається Кабінетом Міністрів України [1].

Так, відповідно до Порядку реєстрації військових частин як суб'єктів господарської діяльності у Збройних Силах, затвердженого постановою Кабінету Міністрів України від 2011 року № 749 (далі Порядок), реєстрації підлягають військові частини, заклади, установи й організації збройних сил (далі - військові частини), що здійснюють господарську діяльність із метою одержання додаткових джерел фінансування життєдіяльності військ (сил) для підтримання на належному рівні їх бойової та мобілізаційної готовності шляхом включення до реєстру військових частин як суб'єктів господарської діяльності [6].

Реєстрація військових частин як суб'єктів господарської діяльності проводиться Мінобороною відповідно до названого Порядку та Положення про порядок ведення реєстру військових частин як суб'єктів господарської діяльності, що ним затверджується.

Виходячи зі змісту Порядку, варто підкреслити, що військова частина як суб'єкт господарської діяльності може:

а) почати здійснювати господарську діяльність після реєстрації;

б) припинити господарську діяльність разом із виключенням із реєстру;

в) змінити вид господарської діяльності шляхом перереєстрації.

При здійсненні реєстрації військової частини як суб'єкта господарської діяльності вона може бути включеною до реєстру або ж їй відмовлять.

Відповідно до Порядку реєстрація проводиться шляхом внесення до Міноборони подання про реєстрацію військової частини як суб'єкта господарської діяльності у збройних силах, до якого додаються реєстраційна картка військової частини як суб'єкта господарської діяльності у Збройних Силах України, довідка про включення військової частини до Єдиного державного реєстру підприємств та організацій України.

Міноборони у десятиденний термін із моменту одержання зазначених документів проводить або відмовляє в реєстрації військової частини як суб'єкта господарської діяльності у збройних силах. У разі позитивного висновку Міноборони видає свідоцтво.

Військова частина у десятиденний термін із моменту одержання свідоцтва інформує про свою реєстрацію податковий орган та орган Державного казначейства за своїм місцезнаходженням. У разі зміни місцезнаходження, найменування та інших відомостей вона в такий же термін зобов'язана в установленому порядку повідомити про це зазначені органи.

Відмова в реєстрації військової частини як суб'єкта господарської діяльності може мати місце в тому випадку, якщо:

- планований вид господарської діяльності не зазначено в переліку видів господарської діяльності, здійснення якої дозволяється військовим частинам;

- здійснення господарської діяльності знижуватиме рівень бойової та мобілізаційної готовності військової частини; 
- у ній відсутня відповідна матеріально-технічна база й умови для здійснення господарської діяльності.

Припиняється господарська діяльність військової частини також за рішенням Міноборони. У цьому разі військова частина виключається 3 реєстру, про що Міноборони повідомляє у п'ятиденний термін податковий орган та орган Державного казначейства за їі місцезнаходженням.

У разі зміни виду господарської діяльності проводиться перереєстрація військової частини як суб'єкта цієї діяльності у збройних силах, про що вносяться зміни у свідоцтво про реєстрацію. Вона здійснюється на підставі подання, до якого додається нова реєстраційна картка.

При зміні умовного або дійсного найменування військова частина протягом п'яти днів із дати прийняття відповідного рішення, а в разі зміни місцезнаходження - протягом п'яти днів із дати завершення передислокації подає до Міноборони нову реєстраційну картку, на підставі якої вносяться зміни у свідоцтво [7].

Висновок. Порядок реєстрації військових частин як суб'єктів господарської діяльності у Збройних Силах України передбачає реєстрацію, зміни найменування та місця знаходження військових частин, а також порядок припинення і зміни виду господарської діяльності, а тому в повному обсязі визначений ії господарсько-правовий статус як суб'єкта господарської діяльності у Збройних Силах України.

\section{ЛIТЕРАТУРА}

1. Закон України «Про господарську діяльність у Збройних Силах України» // Відомості Верховної Ради України. - 1999. - № 48.

2. Кондик П. М., Овсяник В. І. Проблеми правового регулювання економічної та господарської діяльності Збройних Сил України / П. М. Кондик, В. І. Овсяник // Народна армія. - 2007. - № 25 (1718). - С. 4-7.

3. Наказ Міністра оборони України «Про затвердження Положення про військове (корабельне) господарство Збройних Сил України» // Міністр оборони України. - 1997. № 300 .

4. Постанова Кабінету Міністрів України «Перелік видів господарської діяльності, здійснення якої дозволяється військовим частинам Збройних Сил України» // Кабінет Міністрів України. - 2009. - № 1171.

5. Наказ Державного комітету по стандартизації, метрології і сертифікації // Державний комітет по стандартизації, метрології і сертифікації. - 2009. -1996. - № 441.

6. Постанова Кабінету Міністрів України «Порядок реєстрації військових частин як суб'єктів господарської діяльності у Збройних Силах» // Кабінет Міністрів України. - 2011. - № 749.

7. Наказ Міністра оборони України «Про затвердження Положення про порядок ведення реєстру військових частин як суб'єктів господарської діяльності» // Міністр оборони України. - 2007. - № 635.

\section{REFERENCES}

1. Zakon Ukrainy "Pro gospodarsku diylnist y Zbroenih silah Ukraine" [Lex Ucraina Armati Virium et oeconomicos de Ucraina"]. "Widomosti Werhownoi Radu Ukrainu", - 1999r. №48. (in Ukrainian). 
2. Konduk, O. Owsjnik, W. (2007). Problemu hrawowogo reguluwannj ekonomichnoi ta gospodarskoi dijlnosti Zbroinih Sil Ukrainu [Cognoscentium quaestiones de legalis constitutio res oeconomicae activities de Armati Virium de Ucraina]. Narodna armij. 3, 4-7 (in Ukrainian).

3. Nakaz Ministra oboronu Ukrainu "Pro zatwerdgennj Pologennj pro wijskowe (korabelne) gospodarstwo Zbroinuh Sil Ukrainu" [Ordo Ministro Defensionis Ucraina "De probatio militum (navis) facilities de Armati Virium Ucraina"]. Ministr oboronu Ukrainu - 1997.№ 300. (in Ukrainian).

4. Postanowa Kabinety Ministriw Ukrainu "Perelik widiw gospodarskoi dijlnosti, zdijsnennj jkoi dozwoljetsj wiskowum chastunam Zbroinuh Sil Ukrainu" [Quod CISTELLULA de Ministros, Ucraina album of economic De actionibus, quarum licet implementation de signis de Armati Virium Ucraina”]. "Kabinet Ministriw Ukrainu”, - 2009. - №1171. (in Ukrainian).

5. Naraz Dergawnogo komitety po standartuzacii, metrologii I sertufikacii .[Ad quintum pro standardization Committee res publica, rei publicae Committee pro standardization]. "Dergawnuj komitet po standartuzacii, metrologii I sertufikacii" - 2009. - 1996. - №441.(in Ukrainian).

6. Postanowa Kabinety Ministriw Ukrainu "Porjdok reistracii wiiskowuh chasten jk sybektiw gospodarskoi dijlnjsti e zbroinuh Silah Ukrainu". [Ad sextum CISTELLULA de Ministros, Ucraina "De modo procedendi in negotiis et rebus unitates adnotatione de Armati Virium"]. "Kabinet Ministriw Ukrainu", - 2011. - №749. (in Ukrainian).

7. Nakaz Ministra oboronu Ukrainu "Pro zatwerdgtnnj Pologennj pro porjdok wedennj reestry wiiskowuh chastun jk sebektiw gospodarskoi dijlnosti" [Ordo Ministro Defensionis Ucraina“"De probatio processus actis mandare entitatum unitates negotium"]. Ministr oboronu Ukrainu - 2007.- № 635/ (in Ukrainian).

\title{
PЕЗЮМЕ
}

Иван Пискун, кандидат юридических наук, доцент Национальный университет обороны Украины имени Ивана Черняховского

\section{Особенности правового статуса воинской части как субьекта хозяйственной деятельности}

\begin{abstract}
Рассмотрено проблемь дальнейшего усовершенствования правового статуса воинской части как субъекта хозяйственной деятельности в Вооруженных Силах Украины. Определено порядок регистрации хозяйственной деятельности воинских частей Вооруженных Сил Украины. Показано роль Министерства обороны Украины как средства реализации полномочий вочнских частей в сфере хозяйственной деятельности. Сформулированы приоритетные государственные задания по повылению эффективности хозяйственной деятельности в Вооруженных Силах Украины и усовершенствования законодательства Украины касательно правового статуса воинских частей как основного субъекта хозяйственной деятельности.
\end{abstract}

Ключевые слова: вочнская часть; законодательство; хозяйственная деятельность; Министерство обороны Украиньі; Вооруженные Силь Украиньл.

\section{SUMMARY}

Ivan Piskun,

Candidate of sciences Law, Associate Professor

National Defence University of Ukraine

Named after Ivan Cherniakhovskyi

Features of the legal status of the military unit as a subject of economic activity 
Introduction. The modern period is a necessary condition for the successful accomplishment of the tasks set by the before Armed Forces of Ukraine, the legislative definition of the legal status of the military unit as the main subject of economic activity, which entails the appearance of new laws of Ukraine regarding the economic activities of military units. One of such normative legal acts is the Law of Ukraine "On economic activity in the Armed Forces of Ukraine". This, of course, calls for appropriate scientific research aimed at improving the legal status of the military unit, as a business entity, since in the modern period, the Armed Forces of Ukraine have the basic functions for protecting the territorial integrity of Ukraine.

Purpose. The purpose of the article is to study the fundamental provisions of the Ukrainian legislation regarding the existing system of registration of the military unit, as the main subject of economic activity in the Armed Forces of Ukraine, registration, write-off and inventory of military property:

Accordingly, the article focuses on the following main tasks:

to characterize the specifics of the military-economic activity of the Armed Forces of Ukraine at the present stage of their existence, as well as to investigate the state and peculiarities of its legal regulation;

to highlight the legal nature and clarify the concept of economic and income activities carried out by the military units of the Armed Forces;

to determine the economic and legal status of military units, as well as the features of the legal regime of property, enshrined in military units as economic entities.

Methods. The study uses a system of various methods and techniques of scientific knowledge. The methods are dialectic, systemic and formal logical, for which the research is being carried out: the role and place of the institute of the economic activity of the Armed Forces, as well as other related institutions of the economic law in the system of economic legislation of Ukraine, the implementation of the idea of balanced consideration of public and private interests in the specific conditions of the legal regime of management of military units, the ratio of general and special norms of law in this area, the essence (legal nature) of economic activity of The Armed Forces of Ukraine.

Results. Thus, the procedure for registration of military units as economic entities in the Armed Forces of Ukraine envisages registration, change the name and location of military units, as well as the procedure for terminating and changing the type of economic activity, and therefore (in full) its economic and legal status as the subject of economic activity in the Armed Forces of Ukraine.

Key words: military unit; legislation; economic activity; Ministry of Defense of Ukraine; Armed Forces of Ukraine. 